\title{
Dynamism of NF-kB and AP-1 Activation in the Signal Transduction of Ischaemic Myocardial Preconditioning
}

\author{
G. J ancso J . Lantos B. Borsiczky Z. Szanto E. Röth \\ Department of Experimental Surgery, Medical Faculty, University of Pecs, Pecs, Hungary
}

\section{Key Words}

Nuclear factor-kB $\cdot$ Activation protein-1 - Transcription factors · Ischaemic myocardial preconditioning · Signal transduction

\begin{abstract}
Nuclear factor (NF)-KB and activation protein (AP)-1 transcription factors play an important role in the signal transduction of delayed ischaemic preconditioning (PC) leading to myocardial cytoprotection. Because the exact mechanism of the activation of these factors is still not clear, we aimed to monitor the time fluctuation of NF-KB and AP-1 induction in an in vivo animal model. Furthermore, we measured the induction rate of these factors using repeated cycles of PC. Following median thoracotomy, anaesthetized animals ( $24 \mathrm{New}$ Zealand White rabbits) were subjected to ischaemic PC by occlusion of the left anterior descending coronary artery for $5 \mathrm{~min}$. After 10 and $30 \mathrm{~min}$, and 1, 2, 3 and $4 \mathrm{~h}$ of reperfusion, tissue samples were taken from the ischaemic myocardium, and the DNA binding activity of the transcription factors was measured with electrophoretic mobility shift assay. A further 12 animals were subjected to $2 \times, 3 \times$ or $4 \times$ 5 -min ischaemic PC, and after a 30-min or 1-hour reperfusion period, we investigated the possible modulation
\end{abstract}

of NF-kB and AP-1 induction. Our results show significant, biphasically increased NF- $\kappa B$ activity with peak levels at $30 \mathrm{~min}$ and $3 \mathrm{~h}$ of reperfusion in preconditioned myocardium. AP-1 increased monophasically, with the peak level at $1 \mathrm{~h}$ of reperfusion. Repeated PC stimuli enhanced the activity of both transcription factors analyzed, but there was no significant correlation between the number of cycles and the rate of activation. Our results show that the activation of NF- $\mathrm{KB}$ and AP-1 have a specific time curve, and the induction of these factors is only slightly influenced by the number of PC cycles.

Copyright $\odot$ 2004 S. Karger AG, Basel

\section{Introduction}

Ischaemic preconditioning (PC) is a polygenic defensive cellular adaptive phenomenon whereby brief ischaemic stimuli render the heart resistant to subsequent similar stress. The phenomenon was first described by Murry et al. [1], and it was the most intensively examined question in cardiovascular research in the last decade. Ischaemic PC protects against myocardial stunning, reperfusion arrhythmias and infarction, and thus has considerable clinical relevance in treatment of patients with ischaemic heart disease.

\section{KARGER}

Fax +41613061234

E-Mail karger@karger.ch

www. karger.com
(C) 2004 S. Karger AG, Basel

0014-312X/04/0363-0129\$21.00/0

Accessible online at:

www. karger.com/esr
Gabor Jancso

Department of Experimental Surgery, University of Pecs, Medical Faculty

Kodaly Zoltan St. 20

HU-7624 Pecs (Hungary)

Tel. +36 72535 820, Fax +36 72535 821, E-Mail jancsogabor@hotmail.com 
Diverse signalling molecules released by a sublethal ischaemic stress initiate a complex signal transduction cascade that modulates the activation of the severe transcription factors, which lead to the expression of cardioprotective genes. Recent studies have assumed that the activation and translocation of nuclear factor (NF)- $\mathrm{kB}$ and activation protein (AP)-1 are key components in the signal transduction mechanism of ischaemic PC $[2,3]$.

$\mathrm{NF}-\mathrm{\kappa B}$ is a redox-sensitive transcription factor involved in transcription of proteins in response to mutagenic, oxidative and hypoxic stress [4]. Under normal physiologic conditions, NF- $\mathrm{\kappa B}$ is held inactive in the cytoplasm by the inhibitory subunit, inhibitor (I)- $\kappa \mathrm{B} \alpha$ [5]. Under conditions of oxidative stress, NF- $\kappa B$ disassociates from I- $\kappa \mathrm{B} \alpha$ and translocates to the nucleus, where it initiates the transcription of pro-inflammatory, procoagulant and vasoactive genes [6]. In contrast to the role NF$\kappa \mathrm{B}$ activation has in the destructive events of inflammation, NF- $\mathrm{KB}$ also mediates the expression of cytoprotective proteins (heat shock proteins), which block apoptosis or inhibit inflammation in response to several types of cellular stress [7]. In a negative feedback manner, these cytoprotective proteins inhibit NF- $\mathrm{KB}$ [8].

The NF- $\kappa$ B pathway displays the capacity to activate, in a cell- and stimulus-specific manner, only a subset of the total repertoire of NF-kB-responsive genes. The seemingly promiscuous nature of NF- $\mathrm{\kappa B}$ activation poses a regulatory quagmire as to how specificity is achieved at the level of gene expression. Rapid growth in our understanding of signal transduction in general, and NF- $\kappa \mathrm{B}$ in particular, provides intriguing insights as to how this may occur.

AP-1 is another well-characterized eukaryotic transcription factor that is highly regulated by the redox status of the cell. It is composed of various subunits (jun, fos and Fra) as dimers, which recognize with different affinities the AP-1 DNA-binding site. Through the mechanism of reactive oxygen intermediates - generated by ischaemiareperfusion - induction of AP-1 is not known, and alteration of the cell thiol redox status has been shown to induce c-fos and c-jun expression and phosphorylation of jun proteins. Many factors, including ionizing radiation, cytokines, oxidative stress and growth factors, lead to AP1 activation. Similar to NF- $\kappa \mathrm{B}$, activation of AP-1 induces expression of a variety of genes whose protein products may either protect the cells from, or make the cells more susceptible to oxidative stress. Oxidative stress caused by the brief ischaemia-reperfusion of PC induces either NF$\kappa \mathrm{B}$ or AP- 1 activation, and both of them activate pro- and anti-apoptotic signals in vivo in the myocardium.
To understand the role and the detailed regulation of these transcription factors in the phenomenon of ischaemic PC, the purpose of this study was to examine the time fluctuation of NF- $\mathrm{KB}$ and AP-1 levels in the preconditioned myocardium. We measured the DNA binding activity of NF- $\mathrm{KB}$ and AP-1 at various times after brief ischaemic episodes in reperfused myocardium. Furthermore, we aimed to investigate the activation rate of NF$\kappa \mathrm{B}$ and $\mathrm{AP}-1$ in cases of repeated cycles of ischaemic PC.

\section{Materials and Methods}

The present study conforms with the Guide for the Care and Use of Laboratory Animals published by the US National Institutes of Health (NIH Publication No.85-23, revised 1996) and was approved by the local institutional Committee on Animal Research of Pécs University (BA02/2000-29/2001).

\section{Surgical Preparation}

A marginal ear vein was cannulated in New Zealand White rabbits weighing $2.6-3.3 \mathrm{~kg}$ (mean $2.8 \mathrm{~kg}$ ), after local anaesthesia was induced using lidocaine cream. The animals were anaesthetized with intravenous xylazine $(6 \mathrm{mg} / \mathrm{kg})$, ketamine $(6 \mathrm{mg} / \mathrm{kg})$ and propofol $(10 \mathrm{mg} / \mathrm{kg})$. The trachea was intubated (tube internal diameter, $3 \mathrm{~mm}$ ) and the lungs were ventilated (Sulla 808, Drager, Lübeck, Germany) at a frequency of 30-35 breaths/min and a tidal volume of $15-20 \mathrm{ml}$. Anaesthesia was maintained by inhalation of isoflurane (2-4 vol. \%) and nitrous oxide (50 vol. \%).

The chest was opened by midline sternotomy. A 5-0 prolene (Ethicon 5/0,1-metric, TF) ligature was passed around the left anterior descending coronary artery and through a snare. In general, the site of vessel encirclement was on the long axis of the left ventricle towards the apex, approximately one fourth of the distance from the atrioventricular groove to the left ventricular apex. Fifteen minutes after completion of surgical preparation, animals were heparinized with $500 \mathrm{U}$ of heparin sodium. Temperature was measured inside the pericardial cradle (Siemens Sirem, Digital Thermometer, Düsseldorf, Germany) and maintained between 38.3 and $38.7^{\circ} \mathrm{C}$ by adjusting a heating pad and an infrared lamp.

In the ischaemic PC groups, the snare was tightened for $5 \mathrm{~min}$, thereby inducing occlusion of the coronary artery $(5 \mathrm{~min}$ of ischaemia with $10 \mathrm{~min}$ of reperfusion was previously described - and in our pilot infarct size study conferred - as inducing both early and delayed PC in rabbit myocardium [9]). Myocardial ischaemia was readily discernible by the development of a dusky, bulging region of myocardium (careful note was made of anatomic landmarks of this region). The effectiveness of this manoeuvre was verified by the appearance of epicardial cyanosis and by the immediate occurrence of ST segment elevations in the electrocardiogram (ECG; Siemens Sirecust 1260, Düsseldorf, Germany). At the end of the 5-min period of coronary artery occlusion, the suture was released and removed to ensure proper reperfusion, which was verified by the disappearance of the ECG changes within 5 min in every animal.

Experimental Protocol for $N F-\kappa B$ and AP-1 Analysis

In the first series of our experiment, animals (42 rabbits) were randomly divided into 7 groups. In control animals (group 1), the 
heart was excised right after thoracotomy and a tissue sample was taken from the untreated heart. In the preconditioned groups, after a 5-min ischaemic period, animals were assigned to $10 \mathrm{~min}$ (group 2), $30 \mathrm{~min}$ (group 3), $1 \mathrm{~h}$ (group 4), $2 \mathrm{~h}$ (group 5), $3 \mathrm{~h}$ (group 6) or $4 \mathrm{~h}$ (group 7) of reperfusion before tissue samples were taken from the ischaemic zone of the heart (fig. 1).

In the second series of our study, we aimed to measure NF-kB and AP-1 activation after repeated cycles of ischaemia-reperfusion. The animals ( 36 rabbits) were divided into 6 further groups. For NF$\kappa \mathrm{B}$ investigations, the animals were subjected to either $2 \times, 3 \times$ or $4 \times 5 \mathrm{~min}$ of left anterior descending occlusion (groups 8, 9 and 10) with an intermittent 10-min reperfusion, and after $30 \mathrm{~min}$ of reperfusion (NF- $\mathrm{kB}$ showed its activation maximum at $30 \mathrm{~min}$ of reperfusion), tissue samples were taken from the ischaemic zone of the heart. For AP-1, after $2 \times, 3 \times$ or $4 \times 5$ min of ischaemia (in order, groups 11,12 and 13), a 1-hour reperfusion period (AP-1 showed its activation maximum at $1 \mathrm{~h}$ of reperfusion in the first series) was applied, before tissue samples were taken from the ischaemic zone of the heart (fig. 2).

After the experimental period, the hearts were rapidly excised and rinsed in ice-cold physiological saline. The ischaemic zone was excised on the basis of the previously defined landmarks. The tissue was snap frozen in liquid $\mathrm{N}_{2}$, and stored for not more than 3 days at $-82^{\circ} \mathrm{C}$ before electrophoretic mobility shift assay (EMSA) analysis.

\section{Electrophoretic Mobility Shift Assay}

$100 \mathrm{mg}$ of tissues were homogenized in $1 \mathrm{ml}$ of TE buffer $(1.5 \mathrm{mM}$ EDTA, $0.01 M$ Tris base, pH 7.4) containing $10 \mu M$ PMSF. Nuclei were separated from the cytosol by centrifugation at $1,400 \mathrm{~g}$ for $20 \mathrm{~min}$ at $4^{\circ} \mathrm{C}$, and this separation procedure was repeated 3 times. The last pellet was resuspended in 2 volumes of buffer containing $20 \mathrm{~m} M$ HEPES, pH 7.9, 25\% glycerol, $420 \mathrm{~m} M \mathrm{NaCl}, 1.5 \mathrm{~m} M$ $\mathrm{MgCl}_{2}, 0.2 \mathrm{~m} M$ EDTA, $0.5 \mathrm{~m} M$ DTT and protease inhibitors (Complete Mini, Boehringer Mannheim, Germany) and placed on ice for $20 \mathrm{~min}$. After $10 \mathrm{~s}$ of centrifugation, the supernatants were saved, aliquoted and stored.

The protein concentration was determined with the Bio-Rad Protein Assay kit. 5'-End labelling of oligonucleotides was performed using $\left[\gamma^{-32} \mathrm{P}\right]-\mathrm{ATP}$ and T4 polynucleotide kinase (Amersham Pharmacia Biotech Inc., UK) according to the manufacturer's protocol. $20 \mu \mathrm{g}$ of nuclear proteins were mixed with $1 \mu \mathrm{g}$ of poly(dl-dC), $100 \mathrm{ng}$ of non-specific single-stranded oligonucleotide and $4 \mu$ of buffer containing $10 \mathrm{~m} M$ HEPES, pH 7.5, 10\% glycerol, $1 \mathrm{~m} M$ EDTA and $100 \mathrm{mM} \mathrm{NaCl}$. After $15 \mathrm{~min}$ of incubation at room temperature, the mixture was completed with $2 \mu \mathrm{l}$ of ${ }^{32} \mathrm{P}$ oligonucleotide (approximately $100,000 \mathrm{cpm}$ ) and then incubated for another $30 \mathrm{~min}$. DNAprotein complexes were electrophoresed in a $5 \%$ non-denaturating polyacrylamide gel using a Tris base-borate-EDTA buffer system $(\mathrm{pH}$ 8.3) for $2.5 \mathrm{~h}$ at $200 \mathrm{~V}$. Gels were dried and quantitated using an image scanning densitometer (Cyclone PhosphorImager System, Packard I.C. USA)

\section{Infarct Size Assessment}

After the surgical preparation (described above), the threads were pulled through a reinforced tube (internal diameter $2.5 \mathrm{~mm}$, Mallinckrodt Medical, Athlone, Ireland), which was tunnelled subcutaneously to the interscapular space. The chest wound was then closed in layers and air was aspirated from the thorax.

Rabbits were allowed to recover for 10-13 days. Then, under anaesthesia, we made a small incision above the peripheral end of the

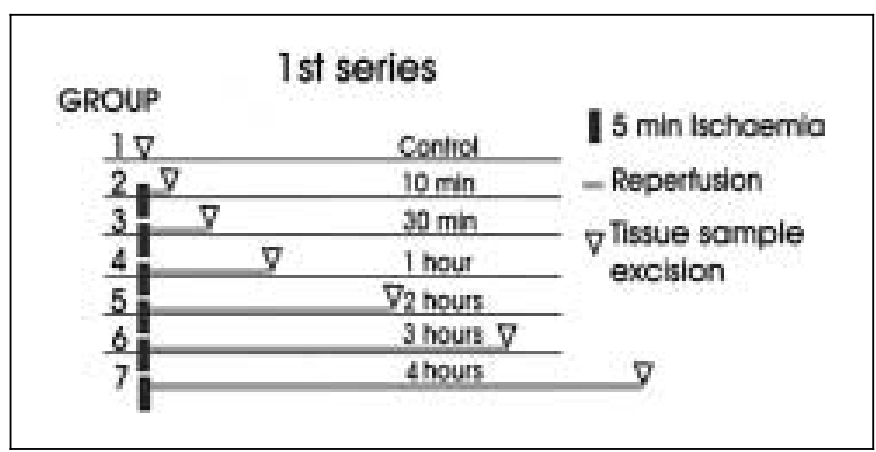

Fig. 1. Experimental protocol of the first series of experiments, to monitor the NF- $\mathrm{KB}$ and AP-1 activation time course in preconditioned myocardium. For details, see Materials and Methods.

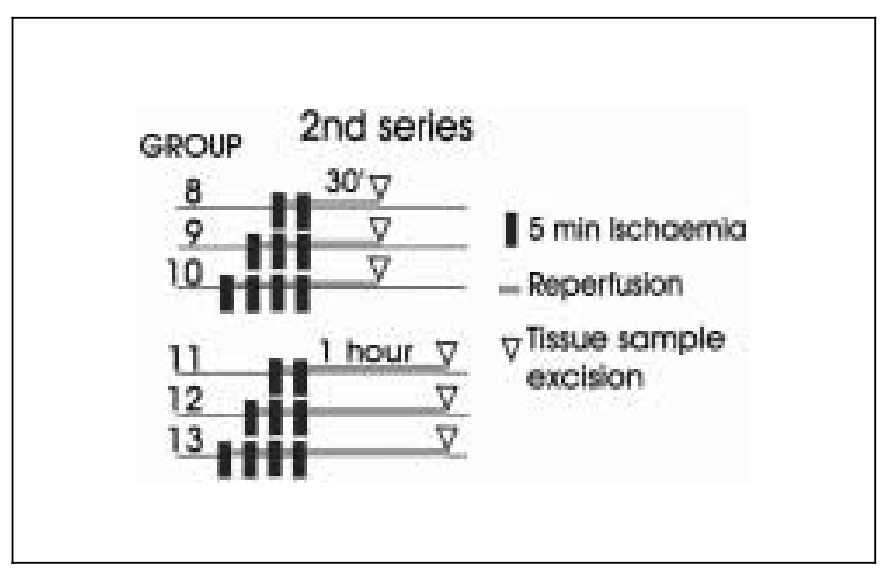

Fig. 2. Experimental protocol of the second series of experiments. Examination of NF- $\kappa$ B and AP-1 activation after repeated cycles of ischaemic PC. For details, see Materials and Methods.

tube, and in preconditioned groups, the suture was tightened, thereby inducing occlusion of the coronary artery. The outgrowth myocardial ischaemia was verified by the ST segment aberrations in the ECG. In the control animals, we performed a sham operation; the suture was not tightened. In preconditioned groups animals were subjected to either $1 \times, 2 \times, 3 \times$ or $4 \times 5$ min of left anterior descending occlusion with an intermittent 10 -min reperfusion. For reperfusion, the suture was released, and the complete reperfusion of the myocardium was verified by the disappearance of the ECG changes within 2 min in every animal.

$24 \mathrm{~h}$ later, after median thoracotomy, the suture around the coronary artery was dissected free. The rabbits were then subjected to $30 \mathrm{~min}$ of coronary artery occlusion by tightening the snare. After $30 \mathrm{~min}$ of occlusion, the snare was released and $2 \mathrm{~h}$ of reperfusion was allowed.

After the reperfusion period, we measured the infarct size with double staining as a percentage of the risk zone. The method of double staining has been described in detail previously [10]. 


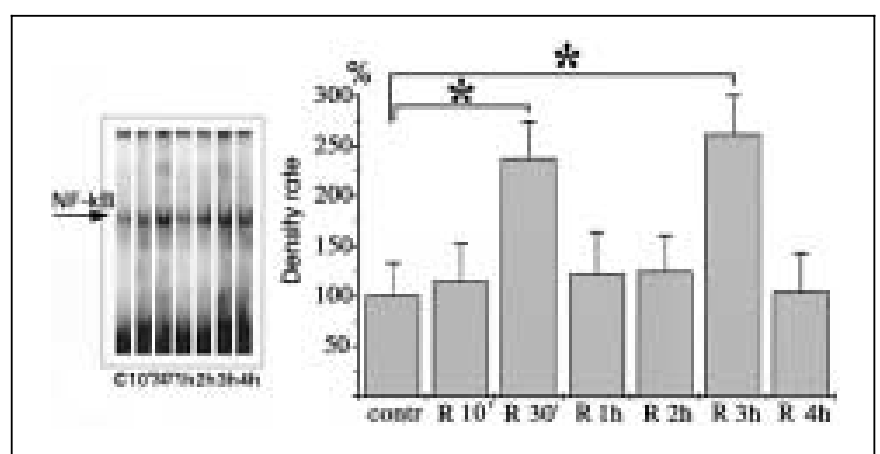

Fig. 3. The time course of NF- $\mathrm{KB}$ activation in the myocardium after ischaemic PC. Activated NF- $\kappa$ B bands (a p50/p65 heterodimer and a p50 homodimer) are shown. Left panel: EMSA analysis. Right panel: densitometry measurements expressed as a percentage of the control. $* \mathrm{p}<0.0001$ versus control.

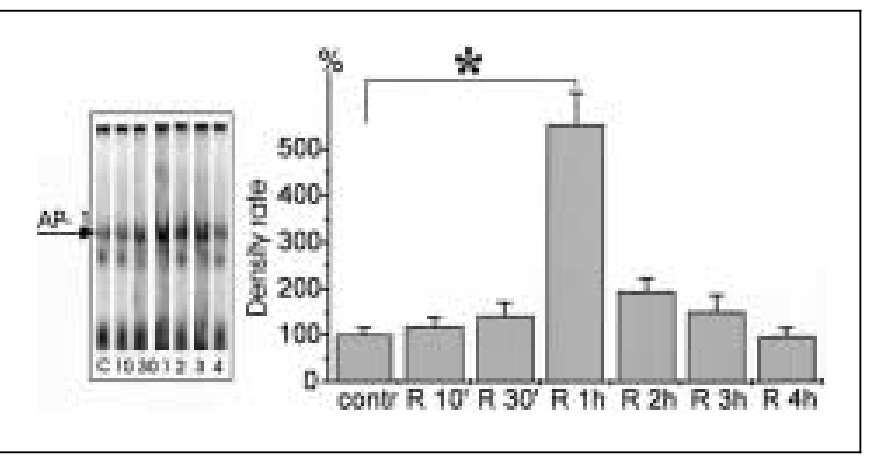

Fig. 4. The time course of AP-1 activation in the preconditioned myocardium. Left panel: EMSA analysis. Right panel: densitometry measurements expressed as a percentage of the control. ${ }^{*} \mathrm{p}<0.001$.

\section{Statistical Analysis}

For statistical analysis, EMSA pictures were evaluated with Cyclone PhosphorImager System densitometry software. The data (mean \pm SEM) for levels of expression of individual protein (EMSA) were subjected to analysis of variance with post hoc Dunnett's onetailed t tests (NF-кB, and AP-1 EMSA), and two-sample Student's t test for significance. Infarct size data were analyzed with one-way analysis of variance followed by an unpaired $t$ test with Bonferroni's correction for multiple comparisons. $\mathrm{p}<0.05$ was considered significant.

\section{Results}

Time Course of NF- $\mathrm{KB}$ and AP-1 Activation

Figure 3 shows changes in NF- $\kappa B$ levels in preconditioned myocardium after various reperfusion times. Specificity of the signal was verified in a competition assay wherein the signal detected by labelled NF- $\mathrm{KB}$ was abolished when the protein homogenate was preincubated with excess unlabelled NF- $\mathrm{KB}$ oligo before the addition of labelled NF- $\mathrm{KB}$. The signal was not abolished when the competition assay contained excess unlabelled non-NF$\kappa B$-binding oligonucleotide. Low and consistent levels of NF- $\kappa \mathrm{B}$ were detected in normal myocardium (untreated, group 1) at steady state. Significantly higher levels were detected after 30 min of reperfusion (group 3) in all 6 animals (densitometry: 2.35 -fold; $\mathrm{p}<0.0001$ vs. controls), and then fell to a lower level at $1 \mathrm{~h}$ of reperfusion. Again at $3 \mathrm{~h}$ of reperfusion (group 6), the levels were significantly higher $(2.59$-fold; $\mathrm{p}<0.0001)$. At $4 \mathrm{~h}$ of reperfusion, the levels decreased to the basic rate, indicating a biphasic regulation (with an emphatic up- and down-regulation) of $\mathrm{NF}-\kappa \mathrm{B}$ in preconditioned myocardium.

Figure 4 shows changes in AP-1 levels in control (untreated) and preconditioned myocardium. After a weak signal elevation at $30 \mathrm{~min}$ of reperfusion, a significant increase in AP-1 levels was detected at $1 \mathrm{~h}$ of reperfusion (group 4$)(p<0.001)$. Though the levels declined gradually, they were still signal at 2, 3 and $4 \mathrm{~h}$ of reperfusion. Preincubation of protein homogenate with excess unlabelled AP-1 consensus oligo abolished specific signals obtained by labelled AP-1, demonstrating the specificity of signals. Signal specificity was established in the abovementioned manner in all cases.

\section{$N F-\kappa B$ and AP-1 Activation after a Repeated Number of Ischaemic Cycles}

One cycle of 5-min ischaemia (group 3) resulted in significant elevation of NF- $\mathrm{KB}$ levels (2.35-fold) compared to controls (group 1) after $30 \mathrm{~min}$ of reperfusion. In the case of further repeated cycles of ischaemia (groups 8, 9 and $10)$, the NF- $\mathrm{KB}$ levels were significantly elevated compared to the controls, but did not result in additional significant accretion of NF- $\mathrm{KB}$ compared to 1 cycle of PC (group 3) (fig. 5).

At $1 \mathrm{~h}$ of reperfusion, 1 cycle of 5 -min ischaemia (group 4) caused a significant rise in AP-1 level (5.43-fold; $\mathrm{p}<0.005$ ) compared to controls (group 1). After repeated PC cycles, AP-1 levels showed analogous results to NF$\kappa \mathrm{B}$. There was no significant difference between the AP-1 levels generated by repeated cycles of ischaemia (groups 11,12 and 13) or 1 cycle of ischaemia (group 4) (fig. 6).

\section{Infarct Size Measurement after a Repeated Number of Ischaemic Cycles}

The ischaemic risk zone volume was similar in all experimental groups at around $19-23 \%$ of the left ventri- 
cle mass. Sham-operated control rabbits had a mean infarct size of $61.3 \pm 12.3 \%$ of the risk zone. PC with a 5 -min coronary occlusion episode limited the infarction to $32.7 \pm 8.6 \%(\mathrm{p}<0.05)$. In the case of further repeated cycles $(2 \times, 3 \times$ or $4 \times 5$ min of ischaemia $)$, the infarct sizes were significantly decreased compared with the controls, but did not result in further significant changes compared to 1 cycle of PC (in order: $29.4 \pm 6.2 \%, 30.9 \pm$ $4.8 \%, 33.1 \pm 7.5 \%)$.

\section{Discussion}

Recurrent episodes of myocardial ischaemia are commonly observed in patients with coronary artery disease who suffer from frequent angina pectoris or angioplasty of the left anterior descending coronary artery. Reversibly injured myocardium (by a short episode of ischaemia followed by another short period of reperfusion) renders the heart more resistant to a longer ischaemic-reperfusion period. Such adaptation - ischaemic PC - is mediated through the up-regulation of the heart's own cellular defence via the accumulation of intracellular mediators and reprogramming of gene expression. Recent studies suggest that the transcription factors NF- $\kappa$ B and AP-1 have a possible role in the signal transduction pathways of this cytoprotection resulting from ischaemic adaptation.

A potential role for $\mathrm{NF}-\kappa \mathrm{B}$ in the endogenous adaptation of ischaemic PC has recently been suggested $[3,11]$. Myocardial protection by $\mathrm{NF}-\kappa \mathrm{B}$ activation may be caused by induction of an NF- $\mathrm{NB}$-regulated mediator, such as manganese superoxide dismutase [12], inducible cyclooxygenase [13] and inducible nitric oxide synthase [14]. Heat shock proteins of the 70-kD family, which are upregulated during PC by other pathways, have been suggested as mediators of ischaemic adaptation [15]. Heat shock proteins modulate AP-1 and NF- $\kappa$ B DNA binding activity $[16,17]$, and might reduce $N F-\kappa B$ activation and thereby reduce inflammation during reperfusion.

The results of our experiments show that there is a biphasic activation of NF- $\kappa \mathrm{B}$ in the preconditioned myocardium, with increased levels at an early time point (30 $\mathrm{min}$ ) and again at $3 \mathrm{~h}$ of reperfusion. It is presumed that there are two different pathways leading to early NF$\kappa \mathrm{B}$ activation after ischaemic PC. Through receptordependent triggers (adenosine $A_{1}$ agonists [18], opioid $\delta_{1}$ agonists [19], bradykinin, prostaglandins, norepinephrine, angiotensin, endothelin), the receptor is coupled through $\mathrm{G}$ proteins to, among others, phospholipase $\mathrm{C}$ (PLC) and D. PLC catalyzes the hydrolysis of membrane

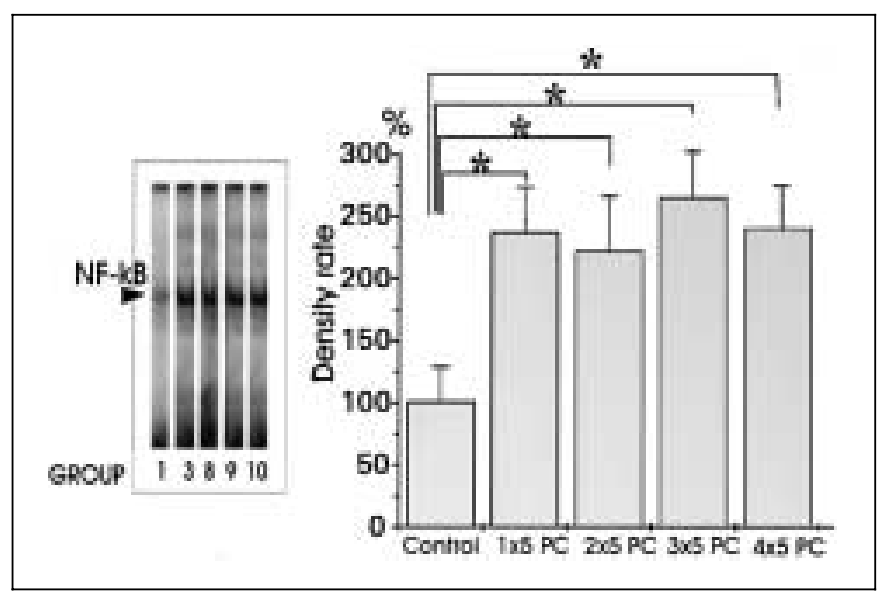

Fig. 5. NF- $\mathrm{KB}$ activation after repeated cycles of ischaemic PC. Left panel: EMSA analysis. Right panel: densitometry measurements expressed as a percentage of the control. $* \mathrm{p}<0.0001$.

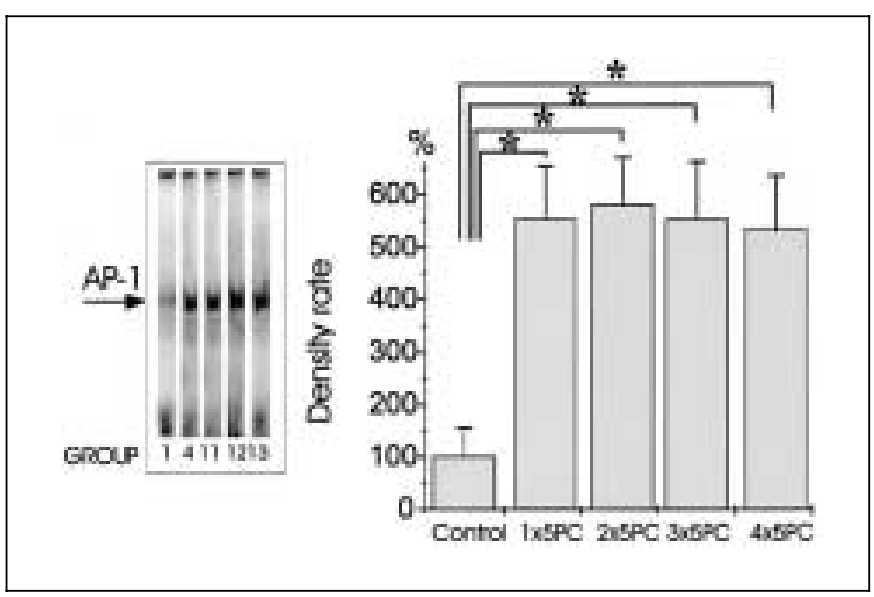

Fig. 6. AP-1 activation after repeated cycles of ischaemic PC. Left panel: EMSA analysis. Right panel: densitometry measurements expressed as a percentage of the control. $* \mathrm{p}<0.001$.

inositol-containing phospholipids into inositol trisphosphate and diacylglycerol (DAG) [20]. DAG stimulates the translocation and activation of protein kinase $\mathrm{C} \varepsilon(\mathrm{PKC} \varepsilon)$. The onset of the PLC reaction is typically very rapid, and DAG production is short-lived, peaking at $30 \mathrm{~s}$ [21]. $\mathrm{PKC} \varepsilon$ activation then triggers a complex signalling cascade that involves Src and/or Lck tyrosine kinases and probably other kinases, leading to phosphorylation of I$\kappa \mathrm{B} \alpha$ and to mobilization (nuclear translocation) and activation of the transcription factor NF- $\mathrm{NB}$ [22].

Another possible pathway of NF- $\mathrm{KB}$ activation in ischaemic $\mathrm{PC}$ is through the increased production of nitric 
oxide [most likely via endothelial nitric oxide synthase (eNOS)] and $\mathrm{O} \dot{\overline{2}}$ (leading to formation of secondary reactive oxygen species) after a brief episode of myocardial ischaemia-reperfusion [23]. Both nitric oxide (NO) and $\mathrm{O} \dot{\overline{2}}$ derived reactive oxygen species could directly activate the $\varepsilon$ isoform of PKC via nitrosylation and oxidative modification, respectively; alternatively, $\mathrm{NO}$ and $\mathrm{O} \dot{2}$ are known to react to form $\mathrm{ONOO}^{-}$, which in turn could activate PKC $\varepsilon$. Thus, PKC is thought to be a critical component in both pathways [24, 25].

Ischaemic PC has recently been found to activate Janus activated kinases 1 and 2 with a subsequent tyrosine phosphorylation and activation of STAT1 and STAT3, which is essential for inducible nitric oxide synthase (iNOS) up-regulation. Binding of NF- $\kappa$ B and STAT $1 / 3$ to the iNOS promoter results in transcriptional activation of the iNOS gene and leads to synthesis of new iNOS protein (eNOS-dependent iNOS induction). iNOS-derived NO is supposed to create a second wave of PKCE activation, leading to the late phase of NF- $\mathrm{KB}$ activation and translocation [26].

The other possible explanation of the late increase in NF- $\kappa \mathrm{B}$ activation might be the feedback mechanism of NF- $\kappa B$-induced pro-inflammatory cytokines (e.g. TNF- $\alpha$, IL-1 $\beta$ ). After ischaemia-reperfusion, even in the case of ischaemic PC, NF- $\kappa \mathrm{B}$ can induce TNF- $\alpha$ and IL- $1 \beta$ gene expression $[27,28]$. Through an unknown mechanism, these cytokines generate a mass of reactive oxygen intermediates in the myocardium, which can - via the abovementioned pathway - newly activate NF- $\kappa \mathrm{B}$ in the cytoplasm and lead to a delayed wave of nuclear translocation of this transcription factor. TNF- $\alpha$ and IL- $1 \beta$ can also start up a signalling pathway leading to I- $\kappa \mathrm{B}$ phosphorylation, and thus NF- $\mathrm{KB}$ activation, through cell membrane receptors [29]. A number of signal transduction proteins have been identified as being associated with these receptors, including TNF receptor-associated factors 2 and 6 , death domain-containing proteins (TRADD and FADD) and kinases associated with the IL-1 receptor (IRAK1 and 2, and MYD88) [30]. These kinases phosphorylate members of the I- $\mathrm{KB}$ family at specific serines within their Ntermini, leading to site-specific ubiquitination and degradation of NF- $\mathrm{KB}$ by the $26 \mathrm{~S}$ proteosome. This circle cascade (NF- $\kappa \mathrm{B} \rightarrow \mathrm{TNF}-\alpha$, IL- $1 \beta \rightarrow$ NF- $\kappa \mathrm{B}$ feedback) might also be an explanation of the biphase activation of NF- $\mathrm{KB}$ after ischaemic PC [30].

The second major observation from our study is the detection of increased AP-1 levels in the preconditioned myocardium. In contrast to NF- $\mathrm{BB}$, for which after an initial increase at $30 \mathrm{~min}$, a second peak was observed at $3 \mathrm{~h}$ of reper- fusion, AP-1 levels increased in a monophasic manner at $1 \mathrm{~h}$ of reperfusion. Though we did not measure the levels of AP-1 during the ischaemic period, in various in vitro systems, a substantial increase in AP-1 levels was demonstrated during hypoxic conditions. In a cancerous cell line (HeLa), Rupec and Baeuerle [31] showed increased NF-kB activity within $15 \mathrm{~min}$ after initiation of reperfusion, while increased AP-1 was detected during hypoxia itself. They argued that during reoxygenation, increased intracellular reactive oxygen intermediates activate existing NF- $\mathrm{KB}$ by dissociation from its inhibitor I- $\mathrm{kB}$, while low levels of free radicals during hypoxia, a condition similar to that observed during antioxidant treatment, induced AP-1.

Because both NF- $\kappa \mathrm{B}$ and AP-1 are activated by cytokines such as IL- 1 and TNF- $\alpha$, the positive synergy between NF- $\kappa \mathrm{B}$ and the subunits of AP-1 might have important implications for both immune and inflammatory responses. Stein et al. [32] showed functional crosscoupling of NF- $\kappa \mathrm{B}$ p 65 and AP-1 families of transcription factors, resulting in increased DNA binding activity of $\mathrm{NF}-\kappa \mathrm{B}$. Both s-fos and c-jun synergised with NF-кB by physically interacting with the p65 subunit [32]. Whether such interaction exists in preconditioned myocardium is not known.

In this report, we also demonstrated the DNA binding activities of NF- $\kappa B$ and AP-1 after different numbers of ischaemia-reperfusion cycles. Our results show that after one cycle of ischaemia-reperfusion, which was previously shown to exert powerful cardioprotective effects for ischaemic hearts, the activation of NF- $\mathrm{KB}$ and AP-1 increased progressively and steadily. However, further numbers of ischaemia-reperfusion cycles did not result in further elevation in activation of NF- $\mathrm{KB}$ and AP-1 compared to the single cycle. These findings correlate with the threshold hypothesis of Goto et al. [33]; they found that ischaemic $\mathrm{PC}$ is an 'all or nothing' response to slight ischaemicreperfusion injury. If the PC stimulus is strong enough to reach a 'threshold' level, a full signaling cascade and protection will be induced, but in cases of subthreshold stimulus, the whole process will fail. Above this threshold, the strength of the PC stimulus does not influence the volume of the signalling cascade and the degree of the evoked cardioprotection [33].

\section{Acknowledgements}

This study was supported by OTKA-T34810 and OTKAT038035 grant. Special thanks to the colleges of the Department of Medical Biology, Katalin Kiss and Prof. Jozsef Szeberenyi for their help with laboratory work. 


\section{References}

1 Murry CE, Jennings RB, Reimer KA: Preconditioning with ischemia: A delay of lethal cell injury in ischemic myocardium. Circulation 1986;74:1124-1136.

2 Xuan YT, Tang XL, Banerjee S, Takano H, Li RC, Han H, Qiu Y, Li JJ, Bolli R: Nuclear factor-kappaB plays an essential role in the late phase of ischemic preconditioning in conscious rabbits. Circ Res 1999;84:1095-1109.

3 Morgan EN, Boyle EM Jr, Yun W, GriscavageEnnis JM, Farr AL, Canty TG Jr, Pohlman H, Verrier ED: An essential role for NF-kappaB in the cardioadaptive response to ischemia. Ann Thorac Surg 1999;68:377-382.

4 Baeuerle PA, Baltimore D: NF-кB: Ten years after. Cell 1996;87:13-20.

5 Beg AA, Baltimore D: An essential role for NF$\kappa \mathrm{B}$ in preventing $\mathrm{TNF}-\alpha$-induced cell death. Science 1996;274:782-784.

6 Brown K, Gerstberger S, Carlson L, Franzoso $\mathrm{G}$, Siebenlist U: Control of I $\mathrm{KB} \alpha$ proteolysis by site-specific, signal-induced phosphorylation. Science 1995;267:1485-1488.

7 Bach FH, Hancock WW, Ferran C: Protective genes expressed in endothelial cells: A regulatory response to injury. Immunol Today 1997;18: 483-486.

8 Cooper JT, Stroka DM, Brostjan C, Palmetshofer A, Bach FH, Ferran C: A20 blocks endothelial cell activation through a NF- $\kappa$ B-dependent mechanism. J Biol Chem 1996;271: 18068-18073.

9 Müllenheim J, Schlack W, Frassdorf J, Heinen A, Preckel B, Thamer V: Additive protective effects of late and early ischaemic preconditioning are mediated by the opening of KATP channels in vivo. Pflugers Arch 2001;442:178187.

10 Jaberansari MT, Baxter GF, Muller CA, Latouf SE, Rőth E, Opie LH, Yellon DM: Angiotensin-converting enzyme inhibition enhances a subthreshold stimulus to elicit delayed preconditioning in pig myocardium. J Am Coll Cardiol 2001;37:1996-2001.

11 Maulik N, Sato M, Price BD, Das DK: An essential role of NFKB in tyrosine kinase signaling of p38 MAP kinase regulation of myocardial adaptation to ischemia. FEBS Lett 1998; 429:365-369.

12 Dana A, Jonassen AK, Yamashita N, Yellon DM: Adenosine A1 receptor activation induces delayed preconditioning in rats mediated by manganese superoxide dismutase. Circulation 2000;101:2841-2848.
13 Shinmura K, Tang XL, Wang Y, Xuan YT, Liu SQ, Takano H, Bhatnagar A, Bolli R: Cyclooxygenase-2 mediates the cardioprotective effects of the late phase of ischemic preconditioning in conscious rabbits. Proc Natl Acad Sci USA 2000;97:10197-10202.

14 Guo Y, Jones WK, Xuan Y-T, Tang XL, Bao W, Wu WJ, Han H, Laubach VE, Ping P, Yang Z, Qiu Y, Bolli R: The late phase of ischemic preconditioning is abrogated by targeted disruption of the inducible NO synthase gene. Proc Natl Acad Sci USA 1999;96:1150711512.

15 Marber MS, Latchman DS, Walker JM, Yellon DM: Cardiac stress protein elevation 24 hours after brief ischemia or heat stress is associated with resistance to myocardial infarction. Circulation 1993;88:1264-1272.

16 Carter DA: Modulation of cellular AP-1 DNA binding activity by heat shock proteins. FEBS Lett 1997;416:81-85.

17 Vayssier M, Favatier F, Pinot F, Bachelet M, Polla BS: Tobacco smoke induces coordinate activation of HSF and inhibition of NFkappaB in human monocytes: Effects on TNFalpha release. Biochem Biophys Res Commun 1998; 252:249-256.

18 Downey JM, Liu GS, Thornton JD: Adenosine and the anti-infarct effects of preconditioning. Cardiovasc Res 1993;27:3-8.

19 Schultz JEJ, Hsu AK, Nagase H, Gross GJ: TAN-67, a $\delta_{1}$-opioid receptor agonist, reduces infarct size via activation of $\mathrm{G}_{\mathrm{i} / \mathrm{o}}$ proteins and $\mathrm{K}_{\text {ATP }}$ channels. Am J Heart 1998;43:H909H914.

20 Eskildsen-Helmond YEG, Gho BCG, Bezstarosti K, Dekkers DH, Soei LK, Van Heugten HA, Verdouw PD, Lamers JM: Exploration of the possible roles of phospholipase $\mathrm{D}$ and protein kinase $\mathrm{C}$ in the mechanism of ischemic preconditioning in the myocardium. Ann NY Acad Sci 1996;793:210-225.

21 Billah MM, Anthes JC: The regulation and cellular functions of phosphatidylcholine hydrolysis. Biochem J 1990;269:281-291.

22 Speechly-Dick ME, Mocanu MM, Yellon DM: Protein kinase C. Its role in ischemic preconditioning in the rat. Circ Res 1994;75(3):586590.
23 Bolli R, Manchikalapudi S, Tang XL, Takano H, Qiu Y, Guo Y, Zhang Q, Jadoon AK: The protective effects of late preconditioning against myocardial stunning in conscious rabbits are mediated by nitric oxide synthase: Evidence that nitric oxide acts both as a trigger and as a mediator of the late phase of ischemic preconditioning. Circ Res 1997;81:1094-1107.

24 Ping P, Takano H, Zhang J, Tang XL, Qiu Y, Li RCX, Banerjee S, Dawn B, Balafonova Z, Bolli R: Isoform selective activation of protein kinase $\mathrm{C}$ by nitric oxide in the heart of conscious rabbits: A signaling mechanism for both nitric oxide-induced and ischemia-induced preconditioning. Circ Res 1999;84:587-604.

25 Vondriska T, Zhang J, Song C, Tang XL, Cao X, Baines C, Pass J, Wang S, Bolli R, Ping P: Protein kinase $\mathrm{C}$ epsilon-Src modules direct signal transduction in nitric oxide-induced cardioprotection: Complex formation as a means for cardioprotective signaling. Circ Res 2001; 88:1306-1313.

26 Xuan Y-T, Tang X-L, Qiu Y, Banerjee S, Takano H, Han H, Bolli R: Biphasic response of cardiac NO synthase isoforms to ischemic preconditioning in conscious rabbits. Am J Physiol Heart Circ Physiol 2000;279:H2360-H2371.

27 Chandrasekar B, Freeman GL: Induction of nuclear factor kappaB and activation protein 1 in postischemic myocardium. FEBS Lett 1997; 401:30-34.

28 Herskowitz A, Choi S, Ansari AA, Wesselingh $\mathrm{S}$ : Cytokine mRNA expression in postischemic/reperfused myocardium. Am J Pathol 1995; 146:419-428.

29 Valen G, Yan ZQ, Hansson GK: Nuclear factor kappa-B and the heart. J Am Coll Cardiol 2001;38:307-314.

30 Mercurio F, Manning AM: NF- $\kappa \mathrm{B}$ as a primary regulator of the stress response. Oncogene 1999; 18:6163-6171.

31 Rupec RA, Baeuerle PA: The genomic response of tumor cells to hypoxia and reoxygenation. Differential activation of transcription factors AP-1 and NF-kappa B. Eur J Biochem 1995;234:632-640.

32 Stein B, Baldwin AS Jr, Ballard DW, Greene WC, Angel P, Herrlich P: Cross-coupling of the NF-kappa B p65 and Fos/Jun transcription factors produces potentiated biological function. EMBO J 1993;12:3879-3891.

33 Goto M, Liu Y, Yang XM, Ardell JL, Cohen MV, Downey JM: Role of bradykinin in protection of ischemic preconditioning in rabbit hearts. Circ Res 1995;77:611-621. 